\title{
Desain Hukum Industri Indonesia: Membangun Sumber Daya Industri Bernilai Transendensi Pancasila
}

\author{
Ahmad \\ Fakultas Hukum Universitas Muhammadiyah Tangerang \\ ahmad.law17@gmail.com \\ Gamal Abdul Nasir \\ Fakultas Hukum Universitas Muhammadiyah Tangerang \\ gamalnasir@ymail.com
}

DOI: $10.23917 /$ jjr.v9i1.8095

\section{Submission \\ Track: \\ Received: \\ 1 Mei 2019 \\ Final Revision: \\ 15 Juni 2019 \\ Available online: \\ 30 Juni 2019 \\ Corresponding \\ Author: \\ Ahmad \\ ahmad.1aw17@gmail.com}

\section{ABSTRACT}

Tujuan: Artikel ini bertujuan untuk merumuskan konsep pembangunan sumber daya industri bernilai transendensi Pancasila

Metodologi: Penelitian ini merupakan penelitian hukum doctrinal dengan pendekatan perundang-undangan.

Temuan: membangun industri (sumber daya) membutuhkan adanya sumber daya manusia, memanfaatkan sumber daya alam, mengembangkan dan memanfaatkan teknologi, mengembangkan dan memanfaatkan kreatifitas dan inovasi juga tersedianya biaya serta penyediaan sumber pembiayaan dengan memperhatikan nilai Ketuhanan, Kemanusian, Persatuan, Kerakyatan dan Keadilan sehingga dapat membawa kemaslahatan bagi manusia dan lingkungan berdasarkan nilai-nilai Ketuhanan.

Kegunaan: Industrialisasi ekonomi harus sejalan dengan nilai-nilai Ketuhanan, kemanusian, persatuan, kerakyatan dan keadilan bagi masyarakat Indonesia agar tidak terjadi kesenjangan/ketimpangan dalam memenuhi kesejahteraan dan kemakmuran masyarakat melalui industrialisasi maka peran negara harus kuat dan berpihak kepada kepentingan umum.

Kebaruan/Orisinalitas: Pembangunan sumber daya industri merupakan usaha bersama untuk kemajuan dan kesejahteraan bersama maka peran negara harus hadir untuk memastikan seluruh rangkaian kegiatan dapat mencapai tujuan bersama dan seluruh rangkaian proses industrialisasi harus sejalan dengan nilai Pancasila..

Keywords: Hukum Industri, Sumber Daya Industri, Transendensi Pancasila. 


\section{PENDAHULUAN}

Kegiatan ekonomi dalam banyak bentuk yang dilakukan oleh perusahaan industri dalam mengelolah barangyang masih mentah menjadi barang mempunyai nilai manfaat yang lebih tinggi adalah bentuk nyata dari industrialisasi ekonomi yang banyak terjadi dewasa ini,untuk mewujudkan masyarakat adil dan makmur sehingga perlu diatur oleh hukum agar dapat memberikan perlindungan terhadap kepentingan publik dan dapat dikenakan sanksi atas setiap pelanggaran yang merugikan kepentingan umum.

Globalisasi ekonomi telah melahirkan bentuk dan model transaksi secara bebas, baik secara regional dengan terbentuknya kelompok negara kawasan maupun lintas regional sehingga hukum tidak boleh vakum maka kaidah-kaidah hukum yang sesuai dengan perkembangan dan kebutuhan serta dinamika masyarakat dunia diperlukan penyesuaian, baik dalam fungsinya agar terjadi ketertiban hukum juga untuk menyelesaikan berbagai bentuk sengketa yang mungkin akan terjadi untuk menjamin kepastian hukum dan keadilan bagi semua pihak yang terlibat sebagai masyarakat ekonomi. ${ }^{1}$

Industrialisasi sebagai dasar pembangunan ekonomi nasional suatu negara secara berkelanjutan dengan memperhatikan bangunan sosial budaya dan lingkungan hidup secara nasional sementara disisi lain harus bersaing dengan masyarakat dunia. Upaya meningkatkan kemampuan untuk bersaing dengan masyarakat dunia dengan cara menghasilkan produk yang berkualitas dan dimungkinkan investasi dengan terbentuknya kegiatan usaha yang kondusif, adanya investasi yang efisiensi yang dijamin oleh hukum juga adanya kemudahan-kemudahan dalam mendukung investasi dikegiatan usaha industri yang membutuhkan lokasi dan kawasan industri.

Namun demikian menurut Bhima Yudhistira (Ekonom INDEF), menilai hambatan industrialisasi di Indonesia dihadapkan pada permasalahan kegiatan investasi, kemampuan bersaing dan tersedianya sumber daya manusia yang unggul. Misalnya pada tahun 2016 kegiatan Penanaman Modal Dalam Negeri (PMDM) disektor jasa mengalami kenaikan dari 37,8\% menjadi 45,6\% tahun 2017. Demikian penanaman modal asing pada sektor jasa juga mengalami kenaikan dari $26,8 \%$ menjadi $40,3 \%$. Sementara porsi kegiatan investasi pada sektor industri pengolahan (manufaktur) oleh Penanaman Modal Dalam Negeri (PMDN) dan

\footnotetext{
${ }^{1}$ Abdul Manan, Makalah Peranan Hukum dalam Pembangunan Ekonomi, 2012.
} 
Penanaman Modal Asing (PMA) menurun dari 54,4\% (2016) menjadi 39,7\% pada tahun 2017. Adapun kemampuan daya saing industri Indonesia masih kalah dengan Vietnam dan Thailand, seperti industri tekstil di Indonesia masih mengandalkan mesin-mesin yang sudah tua dan juga terjadi diindustri strategis lainnya. Hambatan juga terjadi pada tersedianya sumber daya manusia yang berkualitas karena di Indonesia masih mengandalkan sumber daya manusia dengan tingkat pendidikan yang mayoritas lulusan sekolah menengah pertama sehingga menyulitkan pertumbuhan industri (70\% dari seluruh tenaga kerja). ${ }^{2}$

Berdasarkan uraian sebagaimana disebutkan diatas maka menjadi penting dan perlu dilakukan penelitian dan pengkajian atas desain hukum industri dan pembangunan sumber daya industri yang bernilai transendensi Pancasila karena bukan melulu soal investasi, daya saing dan sumber daya manusia tetapi nilai-nilai pancasila harus hadir dalam setiap kegiatan industri dalam merubah bahan mentah menjadi barang yang bernilai guna secara ekonomi sehingga seluruh bentuk kegiatan industrialisasi ekonomi terhadap sumber daya yang ada harus berlandaskan pada nilai transendensi Pancasila.

\section{METODOLOGI PENELITIAN}

Penelitian ini merupakan penelitian hukum doktrinal. Sumber informasi hukum menggunakan bahan hukum primer (peraturan dan dokumen relevan) untuk selanjutnya dilakukan analisis secara kualitatif. Pendekatan yang digunakan adalah pendekatan perundang-undangan. Dalam pendekatan ini, konsep hukum ditemukan dalam peraturan perundang-undangan diantaranya UU Nomor 13 Tahun 2014 Tentang Perindustrian dan Peraturan Pemerintah yang terkait.

\section{PEMBAHASAN}

\section{Desain Hukum Industri Indonesia}

Dasar filosofis yang terkandung dalam desain hukum industri diIndonesia yakni terbentuknya sistem ekonomi kerakyatan Indonesia (adil, Makmur, merdeka, bersatu dan berdaulat) yang berlandaskan pada semangat yang terkandung dalam Pancasila dan UUD 1945. Bangunan ekonomi nasional Indonesia harus kuat sehingga perlu membangun industri

\footnotetext{
${ }^{2}$ Bhima Yudhistira, Sektor Industri Masih Hadapi Banyak Permasalahan Struktural, https://ekonomi.bisnis.com/read/20180331/257/778398/sektor-industri-masih-hadapi-banyak-permasalahanstruktural, diakses hari Selasa tanggal 19 Februari 2019, Pukul 15.30 Wib.
} 
sebagai salah satu pilarnya dengan mengandalkan kekuatan dan kemampuan sumber daya yang dimiliki dengan ciri bangunan industrinya yakni struktur yang kuat, mandiri, sehat dan mampu bersaing dengan memanfaatkan seluruh sumber daya yang dimiliki dan tersebar diseluruh wilayah Indonesia dengan prinsip kerakyatan, keadilan, nilai luhur yang dimiliki bangsa Indonesia yang sesuai dengan kepentingana nasionalnya.

Secara normatif menegaskan, seluruh tatanan dan kegiatan yang berkaitan dengan industri disebut perindustrian sedangkan kegiatan yang mengubah bahan mentah menjadi barang jadi yang memiliki nilai dengan memanfaatkan sumber daya disebut industri. Dalam perkembangannya dikenal jenis industri hijau yakni dalam proses produksinya dilakukan secara efektif dan efisien terhadap sumber daya dengan adanya keselarasan pembangunan industri dan kelestarian lingkungan dan juga dikenal industri strategis yakni memperhatikan kepentingan hajat hidup orang banyak, kepentingan pertahanan dan kemananan nasional.

Pada asasnya industri nasional diselenggarakan dengan asas kepentingan nasional, demokrasi ekonomi, kepastian berusaha yang tersebar secara merata dengan persaingan yang sehat dengan tujuan industrinya sebagai pilar dan penggerak ekonomi nasional dalam mewujudkan struktur industri yang kuat, berdaya saing, mandiri dan maju untuk mewujudkan pemerataan pembangunan dan ketahanan nasional yang sejahtera dan adil.

Secara sistematika hal-hal yang diatur dalam undang-undang perindustrian sebagai berikut; pemerintah selaku penyelenggara urusan perindustrian, rencana induk bangunan industri nasional, kebijakan industri nasional, wilayah industri, bangunan sumber dayanya, menyediakan sarana dan prasarananya, memberdayakan industri, industri yang aman dan selamat, permodalan, fasilitas, komite industri nasional, peran masyarakat, mengawasi dan mengendalikan.

Pemerintah mengatur lebih lanjut dengan PP nomor 41 tahun 2015 tentang pembangunan sumber daya industri. PP tersebut mengatur hal-hal mengenai bangunan tenaga kerja industri, konsultan industri, manfaat dan jaminan tersedianya sumber daya alam, konsep teknologi putar kunci dan jaminan resiko atas pemanfaatan hasil penelitian dan pengembangannya.

Demikian juga PP nomor 29 tahun 2018 tentang pemberdayaan Industri. Pemberdayaan Industri merupakan kebijakan dan upaya pemerintah pusat dan pemerintah daerah yang terencana, terarah, dan terukur untuk memampukan dan memandirikan pelaku industri secara partisipatif untuk peningkatan daya saing. Pemberdayaan industri perlu 
dilakukan secara afirmatif kepada kelompok Industri yang dinilai mempunyai kelemahan, dan perlu diberikan dorongan untuk pertumbuhan dan perkembangannya. Dilihat dari skala usaha Industri dapat dibagi kedalam skala industri yang meliputi industri kecil, industri menengah, dan industri besar. Secara khusus, industri kecil dan industri menengah memiliki karakteristik yang hampir sama sehingga dikelompokkan menjadi satu dengan istilah Industri kecil dan industri menengah (IKM). Dilihat dari fungsi dan sifat, lndustri juga dapat dikategorikan sebagai industri hijau dan industri strategis. Upaya peningkatan penggunaan produk dalam negeri untuk menciptakan pasar bagi produk industri dalam negeri merupakan hal yang sangat perlu dilakukan.

\section{Membangun Sumber Daya Industri Bernilai Transendensi Pancasila.}

Dalam membangun sumber daya industri harus memperhatikan beberapa sektor sebagai berikut; a) sumber daya manusia, b) sumber daya alam, c) teknologi industri, d) kreatifitas dan inovasi, e) pembiayaan (Pasal 15 UU Perindustrian). Membangun sumber daya industrii bernilai transendensi Pancasila dapat dilakukan dengan membangun sistem nilai hubungan antara para pelaku industri (pekerja, pengusaha dan pemerintah) yang berlandaskan pada nilai-nilai keseluruhan sila-sila dalam Pancasila dan spirit pembukaan UUD 1945 yang menghendaki masyarakat yang adil dan makmur dan menjadi bagian dari masyarakat dunia yang menolak segala bentuk penjajahan dan terlibat dalam ketertiban dan perdamaian dunia berdasarkan nilai-nilai kemanusiaan yang universal. ${ }^{3}$

Pemerintah juga mengeluarkanPeraturan Presiden nomor 2 tahun 2018 tetang kebijakan industri nasional tahun 2015-2019, dengan menetapkan sasaran pembangunan industri nasional jangka panjang pada rencana induk pembagunana industri nasional (RIPIN) 2015-2035 dan sasaran pembangunan ekonomi nasional pada rencana pembangunan jangka menengah nasional (RPJMN) 2015, sasaran pembangunan industri nasional periode 20152019 yakni meningkatkan laju pertumbuhana industri pengolahan nonomigas sekitar 5,5\%6,2\%, meningkatkan peran industri pengolahan nonmigas menjadi 18,2\%-19,4\%, meningkatnya ekspor industri dan berkurangnya impor, adanya pemerataan industri, meningkatnya peran industri kecil dan menengah, adanya inovasi dan pemanfatan teknologi,

\footnotetext{
${ }^{3}$ Imam Soepomo, Hukum Perburuhan Bidang Hubungan Kerja, (Jakarta: Jambatan, 1975), hlm. 6-7
} 
membuka lapangan kerja, sumber daya alam dimanfaatkan dengan baik dalam memperkuat ekonomi nasional.

Menurut Poespowardojo dan Hardjatno ${ }^{4}$ sebagaimana dikutip Iwan Nugroho mengatakan, untuk mengatasi keterpurukan ekonomi dan rendahnya sumber daya manusia Indonesia maka kebijakan pembangunan nasional oleh pemerintah dalam upaya mewujudkan kesejahteraan masyarakat Indonesia maka pemabangunan tersebut harus berlandaskan pada nilai-nilai Pancasila dan falsafat hidup bangsa Indonesia termasuk dan tidak terbatas dalam pembangunan sumber daya industri.

\section{a. Membangun Sumber Daya Manusia}

Membangun sumber daya manusia dilakukan untuk menghasilkan sumber daya manusia yang mempunyai kompentensi dalam meningkatkan peran sumber daya manusia Indonesia di bidang industri. Pemerintah, Pemerintah Daerah, pelaku industri, dan masyarakat sebagai pelaku industri harus mengupayakan tersebarnya sumber daya manusia yang mempunyai kompentensi secara merata di Provinsi dan Kota/Kabupaten. Sumber daya manusia yang dimaksud meliputi wirausaha industri, tenaga kerja industri, pembina industri dan konsultan industri (Pasal 16 UU Perindustrian). Sehingga industrialisasi berjalan sesuai dengan target dan sasaran yang direncanakan.

\section{b. Manfaat Sumber Daya Alam}

Sumber daya alam yang diolah dan dimanfaatkan secara efisien (ramah lingkungan dan berkelanjutan) oleh perusahaan yang meliputi seluruh tahapan proses hingga tahap produksi produk industri yang dihasilkan termasuk dampaknya seperti pengelolaan limbah oleh perusahaan industri dan perusahaan kawasan industri. Sehingga menjadi penting adanya sanksi hukum atas pelanggaran terhadap pemanfaatan sumber daya alam berupa sanksi administratif (tertulis), denda, ditutup sementara, izinnya dibekukan sementara (Pasal $30 \mathrm{UU}$ Perindustrian dan Pasal 19 PP No. 41 Tahun 2015 tentang pembangunan sumber daya industri).

Dalam rangka meningkatkan nilai tambah sumber daya alam, Pemerintah mendorong pengembangan industri pengolahan di dalam negeri dengan cara melarang /membatasi eksport sumber daya alam. Pemerintah dan Pemerintah daerah mengatur ketersediaan dan

\footnotetext{
${ }^{4}$ Lihat Iwan Nugroho, Nilai-Nilai Pancasila Sebagai Falsafah Pandangan Hidup Bangsa Untuk Peningkatan Kualitas Sumber Daya Manusia Dan Pembangunan Lingkungan Hidup, Jurnal Konstitusi, Vol. III, No. 2, November 2010, hlm. 109.
} 
pemanfaatan sumber daya alam bagi kepentingan industri dalam negeri (Pasal 31-33 UU Perindustrian). Adanya kewajiban bagi perusahaan industri tertentu dan perusahaan kawasan industri mengelola sumber daya alam sebagai energi, termasuk memanfaatkan air baku, harus sesuai dengan peraturan perundang-undangan yang beraku yakni peraturan yang ditetapkan oleh Menteri (Pasal 34-35 UU Perindustrian).

\section{c. Teknologi Industri}

Pengembangan dan penguasaan serta pemanfaatan teknologi secara optimal harus dilakukan dalam rangka mencapai efisiensi, produktivitas, nilai tambah, daya saing dan industri yang mandiri. Dalam kebijakan memilih, mengadakan dan memanfaatkan teknologi harus memperhatikan aspek kemandirian, keamanan dan lingkungan yang terjaga. Pengadaan teknologi industri dapat dilakukan dengan cara penelitian dan pengembangan, usaha bersama, alih hak lisensi dan atau akusisi teknologi.

Pemerintah dalam pengadaan teknologi dapat menerapkan konsep putar kunci, ${ }^{5}$ dengan keharuskan mengalihkannya kepada pihak teknologi domestik. Kelalaian atas kewajiban tersebut dapat dikenakan sanksi berupa sanksi adminitrasi, denda dan penghentian kegiatan sementara (Pasal 36-39 UU Perindustrian).Pengembangan dan pemanfaatan teknologi industri harus memperhatikan kepentingan nasional. Namun demikian, dimungkinkan dalam pengadaan teknologi industri putar kunci dengan keaharusan dialihkan kepada pihak domestik.

Pemerintah mengatur investasi industri dan melakukan audit sebagai upaya dalam mengendalikan pemanfaatan teknologi industri, sesuai peraturan perundang-undangan. Kegiatan audit yang dilakukan oleh Pemerintah melalui kementerian perindustrian dengan melakukan koordinasi dengan kementerian riset dan teknologi pendidikan tinggi. Hal ini dilakukan oleh perguruan tinggi dalam upaya meneliti dan mengembangkan industri dengan cara bekerjasama dengan perusahaan industri agar terjadi alih teknologi (Pasal 41-42 UU Perindustrian).

\footnotetext{
${ }^{5}$ Konsep proyek putar kunci dilakukan oleh perusahaan dengan melakukan seluruh kegiatan (desain, sampai pengujian operasional sebelum proyek diserahkan kepada perusahaan lain untuk beroperasi), umumnya dikenal dengan istilah BOOT (build, own, operate, transfer). Lihat Ngakan Timur antara (Kepala Badan Penelitian dan Pengembangan Industri/BPPI Kementerian Perindustrian) mengatakan, pemerintah bisa melakukan pengadaan teknologi industri melalui proyek putar kunci (penyedian teknologi wajib melakukan alih tehnologi kepada pihak domestik). https//nusantaranews.co. diakses jumat tanggal 28 Maret 2019 Pukul 20.00 wib
} 


\section{d. Kreativitas dan Inovasi}

Dalam mengembangkan dan memanfaatkan kretivitas dan inovasi masyarakat dalam membangun industri harus memperhatikan budaya industri atau kearifan lokal yang tumbuh dalam masyarakat melalui penyediaan ruang dan wilayah yang cukup sehingga dapat dibangun industri kreatif, pelatihan-pelatihan teknologi, bimbingan, advokasi, fasilitas promosi dan tempat pemasaran atas produk industri kecilnya (Pasal 43 UU Perindustrian).

Pengembangan dan pemanfaatan kreatifitas dan inovasi sebagai pembangunan sumber daya industri yang difasilitasi oleh pemerintah dan pemerintah daerah harus sesuai dengan semangat yang terkandung dalam nilai-nilai Pancasila. Kreatifitas dan inovasi yang dihasilkan melalui industrialisasi mempunyai nilai kebaikan bagi kepentingan kemanusian dan nilai keadilan bagi masyarakat.

\section{e. Pembiayaan}

Tersedianya biaya yang kompetitif untuk pembangunan industri yang berasal dari Pemerintah, Pemerintah Daerah, badan usaha, atau perseorangan dan hanya dapat diberikan kepada perusahaan industri yang berbentuk badan usaha milik negara dan badan usaha milik daerah dengan bentuk pembiayaan berupa pinjaman, hibah atau penyertaan modal (Pasla 44 UU Perindustrian). Bukan hanya tersedianya pembiayaan yang kompetitif tetapi juga pengawasan terhadap penggunaan pembiayaan untuk pembangunan industri sangat penting untuk mencapai tujuan industrialisasi.

Menyediakan alokasi biaya yang akan diberikan kepada perusahaan swasta dalam bentuk penyertaan modal, pinjaman, potongan harga pembelian mesin atau alat dapat dibebankan kepada anggran pendapatan dan belanja negara (Pasal 45 UU Perindustrian). Kemudahan pembiayaan kepada perusahaan industri swasta oleh pemerintah harus sesuai dengan peruntukannya sehingga target pembangunan industri sesuai komitmen memajukan perekonomian nasional.

Pengalokasian pembiayaan dan pemberian kemudahan pembiayaan kepada perusahaan industri swasta dimaksudkan dalam rangka menyelematkan ekonomi nasional yang ketentuannya diatur pada tingkat peraturan Presiden. Hal tersebut, semata-mata bersifat sementara sebagai upaya peningkatan daya saing industri dalam negeri yang secara tehnis ditentukan pada peraturan menteri. Pembiayaan kegiatan industri dilakukan oleh lembaga 
pembiayaan sebagai investasi industri yang ditentukan menurut peraturan perundangundangan (Pasal 46-47 UU Perindustrian).

\section{PENUTUP}

Desain hukum industriharus dilakukan dengan mendesian rangkaian kegiatan ekonomi industri agar seluruh sumber daya yang dimilki dapat menghasilakn nilai tambah dan manfaat yang agar tercapai masyarakat yang adil, makmur, sejahtera, bersatu dan berdaulat dalam persatuan.Membangun sumber daya industri dilakukan melalui peningkatan dan pemanfaatan sumber daya manusia, sumber daya alam, pengembangan dan pemanfaatan teknologi industri, pengembangan dan pemanfaatan kreativitas dan inovasi serta penyediaan sumber pembiayaan harus berlandaskan pada nilai-nilai keTuhanan, kemanusiaan, persatuan, kerakyatan dan keadilan sehingga industrialisasi yang dihasilkan sejalan dengan nilai-nilai Pancasila bukan hanya dalam bentuk gagasan tetapi harus konkrit dalam implementasinya.

\section{REFERENCES}

Abdul Manan, Makalah Peranan Hukum dalam Pembangunan Ekonomi, 2012.

Bhima Yudhistira, https://ekonomi.bisnis.com/read/20180331/257/778398/sektor-industrimasih-hadapi-banyak-permasalahan-struktural.

Iwan Nugroho, Nilai-nilai Pancasila sebagai Falsafat pandangan hidup bangsa Indonesia, Jurnal Konstitusi, Vol. III, No. 2, November 2010.

Imam Soepomo, Hukum Perburuhan Bidang Hubungan Kerja, Jakarta: Jambatan, 1975.

Peraturan Pemerintah Nomor 14 tahun 2015 tentang Rencana Induk Pembangunan Industri Nasional Tahun 2015-2035.

Peraturan Pemerintah Nomor 41 Tahun 2015 tentang Sumber Daya Industri

Peraturan Pemerintah Nomor 142 Tahun 2015 Tentang Kawasan Industri

Peraturan Pemerintah Nomor 29 Tahun 2018 tentang Pemberdayaan Industri

Peraturan Pemerintah Nomor 2 Tahun 2018 tentang Kebijakan Industri Nasional Tahun 20152019.

Undang-Undang Nomor 13 tahun 2014 tentang Perindustrian 